\title{
Interactive infographics as a digital tool for the appropiation of concepts
}

\section{La infografía interactiva como herramienta digital para la apropiación de conceptos}

\author{
FLORES-GONZÁLEZ, Norma†* \& FLORES-GONZÁLEZ, Efigenia
}

Benemérita Universidad Autónoma de Puebla

ID $1^{\text {st }}$ Author: Norma, Flores-González / ORC ID: 0000-0002-4967-8854, Researcher ID Thomson: S-6917-2018, CVU CONACYT ID: 957036

ID $1^{\text {st }}$ Co-author: Efigenia, Flores-González / ORC ID: 0000-0002-8340-9340, Researcher ID Thomson: S-5923-2018, CVU CONACYT ID: 333959

\begin{abstract}
The educational process has changed substantially, migrating to a digital format, where traditional practices and digital resources coincide for the construction and deconstruction of knowledge. According to the previous background, the research focuses on identifying whether interactive infographics as a digital resource allow the appropriation of concepts in different contexts. For this purpose, the study was analyzed quantitatively with 20 undergraduate students and 20 from High School during spring 2021, finding these results: infographics do promote the appropriation of concepts in English and Spanish, thanks to the existing association between such an appropriation and the use of the fundamental characteristics in the design of infographics as visual representations, keywords, and information, which show coherence, cohesion, logical sequence and a relationship between its elements: images, text, hypertext, and hyperlinks. In conclusion, interactive infographics are an adequate resource for conceptual changes in virtual environments.
\end{abstract}

Infographics, Appropriation of concepts, Virtual environments

\begin{abstract}
Resumen
En esta nueva normalidad, el proceso educativo ha cambiado sustancialmente migrando a un formato digital, donde las prácticas tradicionales y recursos digitales coinciden para la construcción y deconstrucción del conocimiento. Tomando en cuenta estos antecedentes, la investigación se centra en identificar si la infografía interactiva como recurso digital permite la apropiación de conceptos en contextos distintos. Para tal objetivo, el estudio se analizó cuantitativamente con la participación de 20 alumnos de licenciatura y 20 de Media Superior, durante primavera 2021, encontrándose como resultados, que la infografía si promueve la apropiación de conceptos en inglés y español, gracias a la asociación existente entre la apropiación de conceptos y el uso de las características fundamentales en el diseño de la infografía tales como representaciones visuales, palabras clave e información, las cuales muestran coherencia, cohesión, secuencia lógica y una relación entre sus elementos: imágenes, texto, hipertexto e hipervínculos. Se concluye que la infografía interactiva es un recurso adecuado para el cambio conceptual en ambientes virtuales.
\end{abstract}

Infografía, Apropiación de conceptos, Ambientes virtuales

Citation: FLORES-GONZÁLEZ, Norma \& FLORES-GONZÁLEZ, Efigenia. Interactive infographics as a digital tool for the appropiation of concepts. Journal Practical Didactics. 2021, 5-14: 10-18

\footnotetext{
*Correspondence to Author (e-mail: norma-fg@hotmail.com)

$\dagger$ Researcher contributing as first author.
} 


\section{Introduction}

The disruption caused by the migration of education to the virtual mode has different implications, and one of them is how to design or adapt the resources of traditional classes to a digital format to achieve specific objectives according to a curriculum. There are indeed countless applications or digital tools for this purpose. Nonetheless, their design requires digital competencies where teachers use information and communication technologies in the educational context with academicpedagogical competencies to make their creation possible.

In the specific case of this research, the digital resource analyzed is infographics as a digital tool for the appropriation of knowledge in different contexts (undergraduate and upper secondary level) and languages (Spanish and English). The study has the following hypothesis: infographics allow the appropriation of concepts in different contexts and languages if the essential characteristics for its design are considered during a conscious reading comprehension process.

\section{Theoretical framework}

Because of the new educational spaces in the contingency stage, different proposals and studies conclude that students show a desirable academic performance if their learning process includes varied resources in congruence with their previous knowledge, interests, learning styles, skills, and competencies with flexible learning. Besides, different multimedia resources support the teaching-learning process, among which infographics are one of them.

\section{Infographics}

It is a graphic format to synthesize specific thematic content through images and text. In the words of Davis and Quinn (2014), infographics are a creative tool that develops critical thinking skills and meaningful learning through graphic representations.
Such a tool should contain pedagogical elements that help to structure thoughts into outlines through paragraphs and main ideas with logical sequence (Kibar \& Akkoyunlu, 2014) to reach the representation of knowledge (Polman \& Gebre, 2015), through keywords, drawings, graphics (Calvo, 2014), concise texts, images or sounds that together convey a message accurately to an audience. In summary, definitions describe infographics as a technological tool where cognitive aspects, comprehension, and effective communication converge (Kos and Sims, 2014), evidenced in a graphic representation. At this point, it is vital to identify the fundamental elements that an infographic must contain to succinctly communicate those cognitive aspects and content extracted from a written document and be considered a didactic tool to promote knowledge learning (Guzmán-Cedillo, Lima and Castilla, 2013).

In addition, Dunlap and Lowenthal (2016) mention that in the infographic, each element has a clear purpose related to the content and learning objective, which facilitates the reading comprehension process. Therefore, drawings, graphics, or audio with text, present a concise and clear message (Taspolat et al., 2017) for the appropriation of knowledge (Valero, 2010; Brigas et al., 2013).

Then, infographics are a visual communication with three fundamental elements: visual (graphic representations), content (statistics, references, and frames), and information (facts) (Ru and Ming, 2014), where a story or thematic content aimed at a specific audience is narrated with own style, easy to read and attractive format for the audience with the inclusion of reliable information, confirmed in respective sources of origin. The three factors have an objective recurrence in the symbolic representation (Balbuena, 2014).

Other authors consider that the key elements are an attractive and brief title, the use of simple language to convey the message (Krauss, 2012), which must be in harmony with the images and the design of the graphic representation (discursive relations) in such a way that, as a whole, they allow the understanding of concepts in a quick, interactive and, above all, entertaining way (García, 2014). 
Moreover, images are a fundamental element in this type of design since they allow the concept to be engraved in the reader's mind as he makes the association between the meaning and the signifier. As a result, infographics must show a discursive sequence like a story that shows relationships between visual representations and information in logical order.

For their part, Taspolat et al. (2017) suggest that the first thing to do to create the infographics is to determine its purpose and audience. Another element is the story or content, which must include a context, scheme with logical order, images, clear, concise information, and registration according to the audience. Furthermore, teachers should check the design, considering the font size, pictures, and colors.

It is crucial to point out that there are different types of infographics like static, animated, and interactive. The first ones are the most ordinary since they are a graphic representation through images and information (Franco, 2005), which is brief, and pleasant to the audience, without neglecting its purpose to present coherent information based on a practical reading.

Animated infographics allow the simulation of reality through the reproduction of static images following a temporal or cycle sequence, ideal for the flow of content, the attraction of students in the learning process, and the development of participation (Chevalier et al., 2016).

Interactive infographics demand active participation from the audience (Cairo, 2008) to browse other pages due to the hypertextuality (Zwinger and Zeiller, 2017) and explore the information or data either individually or collaboratively.

In the three forms of infographics, there is the characteristic of universality: no Spatiotemporal barriers to access the information that makes it a digital tool to potentialize knowledge with a varied and attractive format for the audience.

Nevertheless, students need digital skills to represent their concepts, definitions, or content in any infographic design.
It also requires the support and guidance of the teacher to specify explanations or clarify possible misunderstandings since the successful use of infographics depends on the existing relationships between visual representations, written information, its sequence, contextualization, and hypertextuality according to the technological resources used.

\section{Appropriation of concepts}

Pedagogical innovation and innovative didactics in learning promote the appropriation of knowledge. According to Morales et al. (2018), the concept of appropriation is the form and resources through which the student makes knowledge his own. Here, the cognitive structure plays a vital role since the representation of the concepts is integrated into levels based on his perceptions.

This cognitive structure is the set of ideas that the learner has about knowledge. This appropriation is under two principles: private logic (highly related to intellectual property) and social logic (what we know as common knowledge).

For Mite (2018), the following elements are in the development of knowledge appropriation:

Perception: promotes the interpretation and understanding of the context in which it unfolds, which involves the processing of new information and acquisition of new concepts, organization, and recognition of these.

Attention: it allows gathering information from the context, analyzing it, retaining or rejecting it; a process for learning.

Thinking: is a cognitive process generated along with the development of language that contributes to their knowledge.

Language: is an indispensable tool for the appropriation of new knowledge since it leads to communication through words, images, and graphics, facilitating communication.

Knowledge: is produced from self-reflection, experiences, and its relationship with the object. 
The assimilation of this relationship results in the apprehension of new concepts that the content acquires meaning in the student's life when he learns in terms of its application (Bermúdez and Pérez, 2015).

Moreover, Cañas (2010) points out other elements to generate knowledge and its innovative use in teaching, such as the development of autonomous learning in selfmanagement of knowledge, which promote learning activities related to practical aspects for the resignification of perception based on a cognitive imbalance, ensuring the construction of new knowledge. In this case, the use and generation of concepts are closely related to the use of know-how in a given context, since the prominent the cognitive production (generation of ideal schemes), the greater the ability to abstract and generate concepts, fostering the understanding of specific content (Cañas \& Alonso, 2012).

\section{Methodology}

The study was analyzed from a quantitative perspective (Cruz, Olivares, \& González, 2014) to find out whether the use of infographics as a digital tool allows the appropriation of concepts in different languages and contexts based on the following research questions:

RQ1 Does infographics promote the appropriation of concepts?

RQ2 Is there any association between the main features of infographics and such an appropriation?

It is worth mentioning that to obtain the results analyzed in this stud, initially, a pre-test, an educational intervention (where infographics were the only means for the appropriation of knowledge for four months), and a post-test. According to the latter, the hypothesis: infographics is an adequate tool for knowledge appropriation is confirmed or refuted.

\section{Sample}

The sample includes the total population; 20 undergraduate and 20 high school students belonging to the Benemérita Universidad Autónoma de Puebla.
In the first group, the appropriation of concepts was in English, and the second group, in Spanish, with the same interactive infographics contextualized according to each educational level.

\section{Instrument}

As previously clarified, the study will only analyze the post-treatment. In this phase, subjects from each context took two instruments to e knowledge appropriation quantitatively.

The first instrument consists of a standardized test of 50 items that inquire about the appropriation of basic knowledge related to each student's area, according to the syllabus, general and specific objectives.

Since the present study aims to analyze the students' appropriation of concepts written and orally, the second instrument is a rubric with 20 criteria to evaluate such an appropriation in oral discourses that arise from interactive infographics.

\section{Data collection}

Both instruments were applied in the spring of 2021 , once the students had worked for four months with infographics.

The application of the instruments took place in two days. On the first day, subjects took the standardized test, and on the second day, the rubric to assess them in the appropriation of concepts in oral speeches.

Subsequently, SPSS software treated the data quantitatively.

\section{Analysis models}

\begin{tabular}{|c|c|c|}
\hline $\mathbf{R Q}$ & Instrument & Purpose \\
\hline RQ1 & Standardized test & $\begin{array}{l}\text { Measuring } \\
\text { appropriation } \\
\text { concepts }\end{array}$ \\
\hline $\mathrm{RQ2}^{2}$ & $\begin{array}{l}\text { A rubric to evaluate } \\
\text { the appropriation of } \\
\text { concepts in their } \\
\text { oral speeches. }\end{array}$ & $\begin{array}{l}\text { Identify the possible } \\
\text { association between the } \\
\text { main features of } \\
\text { infographics and the } \\
\text { appropriation } \\
\text { concepts. }\end{array}$ \\
\hline
\end{tabular}

Table 1 Analysis model

Source: Own Elaboration 


\section{Results}

RQ1. Does the infographic promote the appropriation of concepts?

The following graph shows the results obtained in the standardized test in both the diagnostic and post-treatment at the Bachelor's and High School levels.

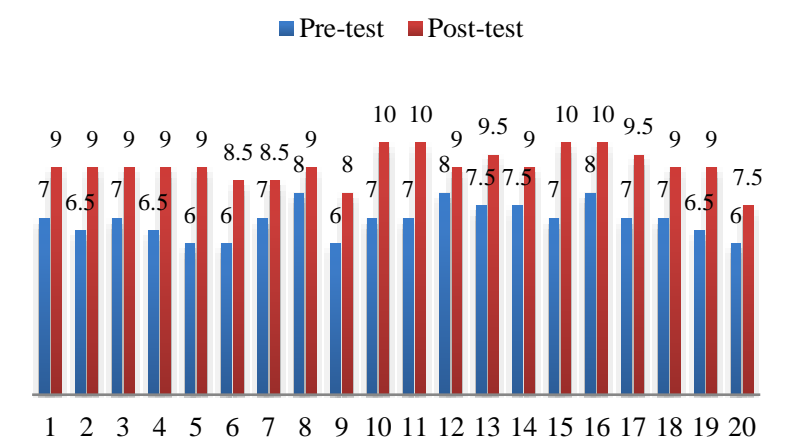

Graph 1 Results of standardized test to measure knowledge appropriation in English Source: Own Elaboration

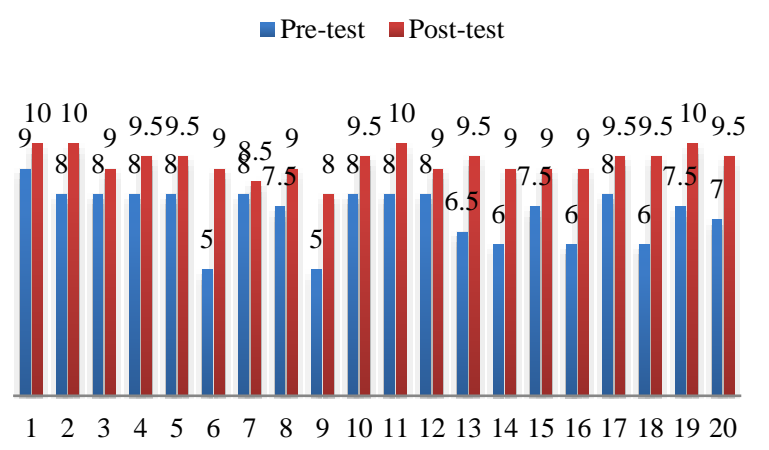

Graph 2 Results of standardized test to measure knowledge appropriation in Spanish

Source: Own Elaboration

As seen in both tables, the data show that infographics as a digital tool promote the appropriation of concepts in different languages and educational levels in the teaching and learning process. The results also permit deducing that using technological resources in the classroom is a positive element that contributes to the student's attention and thus increases their interest and motivation in their immersion process in virtual learning environments.

However, it is crucial to know what elements affect or influence this process for students' appropriation of concepts (knowledge) that contribute to their academic performance, as shown in the previous graphs.
That is why the second research question is necessary.

\section{RQ2. Is there any association between the main infographic features and concept appropriation?}

For interpretative purposes of the infographics features used by students during oral discourses, they are into three prototypes of interactive infographics: A, B, and C. The first includes keywords and moving graphic representations related to the title and hypertext elements. However, they do not present a linkage-logical sequence and lack discursive relationships and hypertextuality.

The second contains fundamental aspects of infographics as title, concepts expressed through graphic representations, and definitions described in the text. They have hypertexts to deepen the meaning of the concept, too. There is also a logical sequence of the story in the visual representation, all facts provide reference sources, and in some cases, it has statistical content.

The third one demonstrates elements of a more interactive infographic, including prototype B, hyperlinks to interactiveexplanatory videos of the concept, and examples of its usage in different contexts and its respective meanings. Moreover, students perform an active role when explaining their infographic, which denotes the appropriation of concepts and the absence of misconceptions. Graph 3 below shows the results of the elements found during the evaluation of oral speeches with the undergraduate students' infographics.

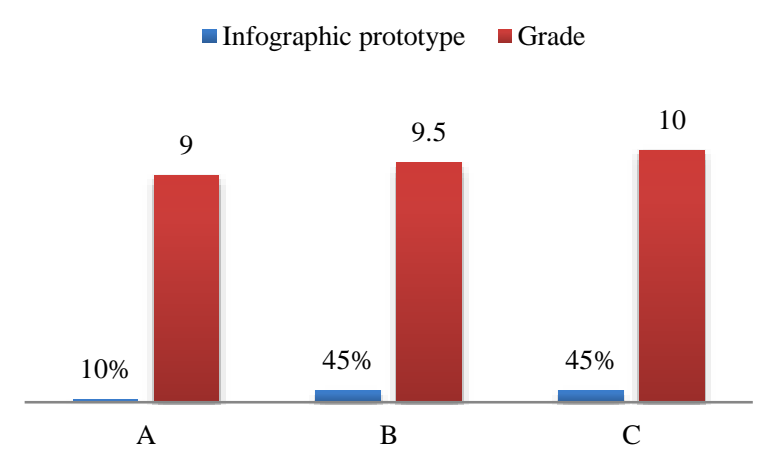

Graph 3 Identification of main characteristics of infographics and their possible association with the appropriation of concepts in English at the undergraduate level

Source: Own Elaboration

FLORES-GONZÁLEZ, Norma \& FLORES-GONZÁLEZ, Efigenia. Interactive infographics as a digital tool for the appropiation of concepts. Journal Practical Didactics. 2021 
As shown in the graph, $10 \%$ used prototype $A, 45 \%$ used prototype $B$, and the rest of the sample used prototype $C(45 \%)$.

Even though with the three infographics the students obtained an acceptable academic performance, which contributes to confirming that infographics do promote the appropriation of concepts, definitely with prototype $\mathrm{C}$, which includes interactive infographics with hypertext and multimedia resources, higher performance and higher grades were obtained, compared to prototypes A and B. These data allow us to make the following assumptions:

1. There is an association between the elements of an infographic and the students' appropriation of concepts.

2. The infographic is a visual representation that, by way of synthesis, presents a complete thematic, with visual and discursive linkage through relationships between concepts and their definitions (Ru and Ming, 2014; Dunlap and Lowenthal, 2016; Taspolat et al., 2017).

3. The use of images, sounds, videos, and hypertexts foster concepts. Therefore, they are must elements to reinforce understanding and offer the reader a simple and attractive comprehension process, but at no time are they a decorative part of the educational tool (infographics), which implies avoiding their excessive use (Franco, 2005).

4. Hypertextuality and video hyperlinking were identified as important characteristics that influence the results of knowledge appropriation in English. It is possible because these resources allowed students to access more visual and auditory representation through processes such as perception (processing of new concepts), attention (information gathering), thinking (organization of ideas), language (appropriation of new knowledge), knowledge (relationship with the object), and assimilation (apprehension of new concepts) (Mite, 2018).

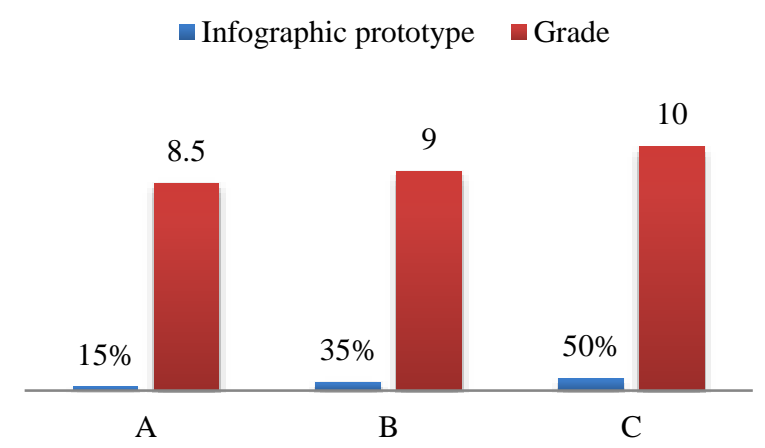

Graph 4 Identification of the main characteristics of infographics and their possible association with the appropriation of concepts in Spanish at High school Source: Own Elaboration

As in the undergraduate level, at High school, students used three infographic prototypes, and as in the previous case, prototype $\mathrm{C}$ shows the highest academic performance. In this case, students who used prototype A obtained 8.5 in their oral speeches, those who used $\mathrm{B}, 9$, and $\mathrm{C}, 10$, respectively.

These data allow us to make the following interpretations:

1. Prototype $\mathrm{C}$ allows a clearer and deeper understanding and appropriation of concepts avoiding misconceptions, thanks to the relationship of visual representations and fundamental concepts, semantic and discursive relationships, contextualized in that interactive infographics.

2. The visual flow of the topic and the presence of a logical sequence (Taspolat et al., 2017) among concepts, text, hypertext (Zwinger and Zeiller, 2017), and hyperlinked multimedia elements provide coherence and cohesion to the graphic representation. Those elements make possible the appropriation of knowledge innovatively.

3. Constant and interactive students' participation with infographics (Cairo, 2008) promotes knowledge appropriation. 
4. The strategy of designing infographics with information and communication technologies focuses the student's visual attention, enabling the appropriation of concepts more simply with the construction and deconstruction of knowledge until the assimilation. In addition, this digital tool facilitates the review of concepts regardless of time or space, contributing to the long-term retention of information since the visual representation remains lodged in the mind.

5. Infographics provide an added value by generating and sharing knowledge because the user develops critical thinking and incorporates previous learning into the appropriation of new concepts.

Based on the results found in the two contexts analyzed, there is an association of the characteristics or attributes of infographics with the appropriation of concepts. The following lines describe them.

1. Keywords or concepts, which are part of the structure of the graphic representation and denote the identification of signifiers by the student.

2. Information. It alludes to the meanings of each concept and contains textual grammar, semantic structure, principal, and secondary ideas with a register $a d$ $h o c$ to the audience.

3. Relationships between visual representations (images, text, hypertext, and hyperlinked digital objects) that show cause-effect, contrast, consequence, and comparison in a specific context enabling understanding of a topic.

4. Logical sequence or linkage among visual representations, text, hypertext, and hyperlinked digital objects contribute to the coherence and global cohesion of the graphic.
5. Design according to the audience. It allows capturing the reader's attention and appropriating new concepts from multimedia graphic representations.

\section{Conclusions}

The results demonstrate that interactive infographics are a didactic digital resource that promotes the appropriation of concepts in English or Spanish at different educational levels, which confirms the hypothesis of this research. They are also recognized as an instructional and learning environment based on technology, and therefore, easily adaptable to virtual learning environments whose effectiveness depends on the implementation of the fundamental characteristics of the infographics in the design since the study evidenced the association between attributes and the appropriation of concepts, potentiating autonomous learning experiences according to the learning styles of the users. At this point, the relevance of this study lies, being one of its contributions to the current educational modality. Finally, this research provides a guideline for future research because it is necessary to determine the correlation between the characteristics of infographics and the appropriation of concepts by users.

\section{References}

Balbuena, M. L. (2014). Teoría de la Representación Simbólica en la Comunicación Gráfica: Barcelona: UAB

Bermúdez, R. \& Pérez, L. (2015). Concepción de los procesos formativos en la educación técnica y profesional. La Habana, Cuba: MINED.

Brigas, J., Gonçalves, J., y Milheiro, S. (2013). Proceedings Book for The Conference on Enabling Teachers for Entrepreneurship Education. Instituto Politécnico de la Guarda, Portugal.

Cairo, A . (2008). La paradoja de las barras y los círculos. Página Personal de Alberto Cairo. Consultada el 4 de marzo de 2021. Disponible en:

http://www.albertocairo.com/infografia/articulo s/2008/circulos.html. 
Calvo, C. (2014). Motion Graphics. infográficos en temáticas sociales (Tesis: Doctorado).Universidad Politécnica de Valencia. Recuperado de: https://riunet.upv.es/handle/10251/45153

Cañas, C., \& Alonso, F. (2012). Factores de la enseñanza que favorecen el aprendizaje autónomo en torno a las actividades de aprendizaje en la educación a distancia. Recuperado de: http://reposital. cuaed. unam. $\mathrm{mx}, 8080$.

Cañas, F. A. C. (2010). Factores de la enseñanza que favorecen el aprendizaje autónomo en torno a las actividades de aprendizaje. Reflexiones teológicas, (6), 167195.

Chevalier, F., Riche, N. H., Plaisant, C., Chalbi, A., Hurter, C. Animations 25 years later: New roles and opportunities. In Proceedings of the International Working Conference on Advanced Visual Interfaces, AVI 2016, Bari, Italy, June 710, 2016 (2016), pp. 280- 287. Doi: 10.1145/2909132.2909255. 1, 2, 3

Cruz, C., Olivares, S., \& González, M. (2014). Metodología de la Investigación. México, D.F.: Grupo Editorial Patria.

Davis, M., \& Quinn, D. (2014). Visualizing text: The new Literacy of Infographics. Retrieved from: https:// www.academia.edu/5615673/Visualizing_Text _The_New_Literacy_of_Infographics

Dunlap, J. C., y Lowenthal, P. R. (2016). Getting graphic about infographics: design lessons learned from popular infographics. Journal of Visual Literacy, 35 (1), 42-59. http://dx.doi.org/10.1080/1051144X.2016.1205 832

Franco, G. (2005). La infografía periodística. Las Palmas de Gran Canaria: Anroart

García, E. M. (2014). Uso didáctico de las infografías. Espiral. Cuadernos del Profesorado, 7(13), 37-43. Recuperado de: http://www.cepcuevasolula.es/espiral/articulos/ ESPIRAL_VOL_7_N_14_ART_4.pdf
Guzmán-Cedillo, Y., y Lima, N. (2013) La evaluación de infografías a través de rúbricas: un primer paso. Ponencia en el XXIX Simposio Internacional de Computación en Educación SOMECE. Ciudad de México (9-13 noviembre).

Kibar, P. N., \& Akkoyunlu, B. (2014, October). A new approach to equip students with visual literacy skills: Use of infographics in education. In European Conference on Information Literacy (pp. 456-465). Springer, Cham.

Kos, B. A., y Sims, E. (2014). Infographics: The New 5-Paragraph Essay. 2014 Rocky Mountain Celebration of Women in Computing. Laramie.

Krauss, J., (2012). More than words can say: infographics. Learning and leading with technology, 5(39), 10-14. Recuperado de: http://crossroadsnorthlibrary.pbworks.com/w/fil e/fetch/53867217/Learning\%20and\%20Leading $\% 20$-\%20February\%202012.pdf

Mite, G. A. (2018). Tesis. Recuperado de http://repositorio.ug.edu.ec/handle/redug/35624

Morales, Y., Aguilar, V., \& Rodríguez, C. (2018). Los medios de enseñanza para la apropiación de contenidos profesionales. Mendive. Revista de Educación, 16(1), 65-78. Recuperado en 6 de septiembre de 2021, de http://scielo.sld.cu/scielo.php?script=sci_arttext \&pid=S1815-

$76962018000100065 \& \operatorname{lng}=$ es\&tlng=es.

Polman, J. L., y Gebre, E. H. (2015). Towards Critical Appraisal of Infographics as Scientific Inscriptions. Journal of Research in Science Teaching, $\quad 52 \quad$ (6), 893.http://dx.doi.org/10.1002/tea.21225

Ru, G., y Ming, Z. (2014). Infographics applied in design education. Advanced Research and Technology in Industry Applications (WARTIA), 984-986.

Taspolat, A., Kaya, O. S., Sapanca, H. F., Beheshti, M., y Ozdamli, F. (2017). An Investigation Toward Advantages, Design Principles and Steps on Infographics in Education. International Journal of Sciences and Research, 73 (7), 157-166. 
Valero, J. L. (2010). La infografía al servicio de la comunicación de la ciencia, Revista Universitas Científica, 1(13), 64-67.

Zwinger, Sandra y Zeiller, Michael (2017): "Utilization and Acceptance of Interactive Infographics in Online Newspapers". Recuperado el 24 de junio de 2021 de http://ffhoarep.fhooe.at/bitstream/123456789/1011/1/Panel_118_ ID_228.pdf 